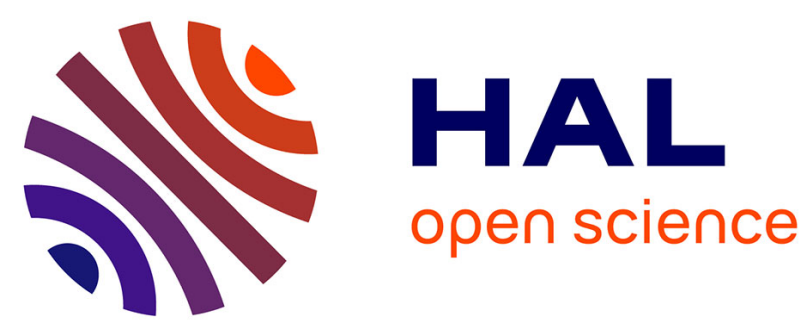

\title{
On the inhibitory effect of some steroids on spermatogenesis in adult rainbow trout (Salmo gairdneri)
}

Roland Billard, Bernard Breton, Murielle Richard

\section{- To cite this version:}

Roland Billard, Bernard Breton, Murielle Richard. On the inhibitory effect of some steroids on spermatogenesis in adult rainbow trout (Salmo gairdneri). Canadian Journal of Zoology, 1981, 59, pp.1479-1487. 10.1139/z81-201 . hal-01601003

\section{HAL Id: hal-01601003 \\ https://hal.science/hal-01601003}

Submitted on 2 Jun 2020

HAL is a multi-disciplinary open access archive for the deposit and dissemination of scientific research documents, whether they are published or not. The documents may come from teaching and research institutions in France or abroad, or from public or private research centers.
L'archive ouverte pluridisciplinaire HAL, est destinée au dépôt et à la diffusion de documents scientifiques de niveau recherche, publiés ou non, émanant des établissements d'enseignement et de recherche français ou étrangers, des laboratoires publics ou privés.

\section{다(1)(2)}

Distributed under a Creative Commons Attribution - ShareAlikel 4.0 International 


\title{
On the inhibitory effect of some steroids on spermatogenesis in adult rainbow trout (Salmo gairdneri)
}

\author{
R. BILLARD \\ Institut National de la Recherche Agronomique, Laboratoire de Physiologie des Poissons, 78350 Jouy en Josas, France \\ B. BRETON \\ Institut National de la Recherche Agronomique, Laboratoire de Physiologie des Poissons, Campus de Beaulieu, \\ 35042 Rennes, France \\ AND \\ M. RICHARD \\ Institut National de la Recherche Agronomique, Laboratoire de Physiologie des Poissons, 78350 Jouy en Josas, France \\ Received December 28, 1980
}

Billard, R., B. Breton, and M. Richard. 1981. On the inhibitory effect of some steroids on spermatogenesis in adult rainbow trout (Salmo gairdneri). Can. J. Zool. 59: 1479-1487.

To test the antifertility effect of various steroids, fish were fed a diet containing steroids at two stages of the reproductive cycle: during spermatogenesis (June to November, experiment A) and during spermiation (November to February, experiment B). The fish in experiment A were given testosterone $(T)$, methyltestosterone $(\mathrm{MT})$, estradiol-17 $\beta\left(\mathrm{E}_{2}\right)$, hexestrol $(\mathrm{H})$, progesterone $(\mathrm{Pg})$, and FGA (Fluorogestone acetate) at doses of 0.05 and (or) $0.5 \mathrm{mg} / \mathrm{kg}$ of food. In experiment B, T, MT, and $\mathrm{E}_{2}$ were given at a dose of $0.5 \mathrm{mg} / \mathrm{kg}$ of food. The fish received a daily ration amounting to $1 \%$ of their body weight. In experiment $\mathrm{A}$, inhibition of testicular growth was total with $0.5 \mathrm{mg} \mathrm{MT}$ and $0.5 \mathrm{mg} \mathrm{E}$ and partial with $0.5 \mathrm{mg} \mathrm{T} / \mathrm{kg}$ of food. In these groups, there was no noticeable change in plasma gonadotropin (GTH) compared with the controls, except that the GTH rise observed in the other groups in September was prevented. This suggests that steroids act directly at the level of the gonad. In experiment B, no noticeable regression of the gonad occurred after steroid treatment. A big GTH rise was seen in the $\mathrm{E}_{2}$-treated group, but this was not followed by stimulation of spermiation. The total amount of sperm $(50 \%)$ and spermatozoa collected during the experiment tended to be lower in the steroid-treated fish than in the controls. Spermatozoal fertilizing ability was significantly decreased $(P<0.005)$ by the testosterone treatment.

Some inhibitory action of sex steroids on gonadal development and spermatogenesis in salmonids has been reported. Steroids given by intraperitoneal injection, in the diet, or by immersion of juveniles before or at the time of sex differentiation sometimes induce sterilization and also sexual reversion or hermaphroditism (Jalabert et al. 1975; Yamazaki, 1976; Johnstone et al. 1978; Goetz et al. 1979). When given to older, underyearling or yearling, prepuberal fish, methyltestosterone, used as a growth promoter, sometimes inhibits gonadal development (Fagerlund and McBride 1975; Higgs et al. 1977; Fagerlund et al. 1979) or stimulates spermatogenesis (McBride and Fagerlund 1976; Fagerlund and McBride 1977). The effects of steroids on adult males are not well documented.

The mode of action of steroids given in the diet on gametogenesis is not known. They may act directly on the gonad or indirectly via the hypothalamo-pituitary axis, stimulating or inhibiting the synthesis and secretion of gonadotropin(s); these effects vary according to species, age and the stage of the sexual development of the fish.

In the present experiment, the inhibitory effect of various steroids added to the diet was tested on spermatogenesis in adult rainbow trout undertaking their second reproductive cycle. Food containing steroids was given during the period of spermatogenesis (JuneOctober, experiment A) and spermiation (NovemberFebruary, experiment B). The effects of the treatment were assessed by observation of changes in gonadotropin $(\mathrm{GTH})$ and in the weight and the structure of the gonad.

\section{Material and methods}

\section{Experiment $A$-treatment during spermatogenesis}

Two-year-old fully mature (running stage) males, originating from the Forgeot fish farm were brought to the laboratory and held in recycled, filtered water in our experimental facilities. They were kept on a normal diet (1\% body weight) until the experiment began on June 18. Before and during the experiments, the fish were under natural photoperiod; daily mean water temperatures fluctuated between 10 and $19^{\circ} \mathrm{C}$. The fish were individually tagged and weighed at the beginning of the experiment and divided into 11 groups of 15 males each. From June 18 to November 18, they were given food containing various steroids at different doses (see Table 1). The androgens and estrogens (Roussel) and the synthetic progestagen FGA (Fluorogestone acetate Searle) were first dissolved in the oil part of the diet before mixing and pelleting 
TABLE 1. Some effects of steroid treatment during spermatogenesis in rainbow trout

\begin{tabular}{|c|c|c|c|c|c|c|c|c|}
\hline Treatment & $\begin{array}{c}\text { Dose of } \\
\text { steroids, } \\
\mathrm{mg} / \mathrm{kg} \text { food }\end{array}$ & $\begin{array}{l}\text { No. of } \\
\text { fish }^{a}\end{array}$ & $\begin{array}{l}\text { Final body } \\
\text { weight, } \mathrm{g}\end{array}$ & $\begin{array}{c}\text { GSI, } \\
\%\end{array}$ & $\underset{\%}{\mathrm{HSI}}$ & $\begin{array}{l}\text { PSI, } \\
\text { ppm }^{b}\end{array}$ & $\begin{array}{l}\text { Percentage of } \\
\text { males sterile }\end{array}$ & $\begin{array}{l}\text { Percentage of } \\
\text { males showing } \\
\text { spermiation }^{d}\end{array}$ \\
\hline Control & & 7 & $204 \pm 71$ & $4.9 \pm 1.8$ & $1.5 \pm 0.4$ & $2.8 \pm 1.5$ & 0 & 100 \\
\hline Testosterone & $\begin{array}{l}0.05 \\
0.5\end{array}$ & $\begin{array}{l}2^{e} \\
9\end{array}$ & $\begin{array}{l}380-290 \\
237 \pm 39\end{array}$ & $\begin{array}{l}8.6-6.7 \\
1.7 \pm 1.5^{*}\end{array}$ & $\begin{array}{c}1-1.1 \\
1.4 \pm 0.3\end{array}$ & $\begin{array}{l}1.4-2.1 \\
3.8 \pm 1.2\end{array}$ & $\begin{array}{r}0 \\
55\end{array}$ & $\begin{array}{r}100 \\
22\end{array}$ \\
\hline $\begin{array}{l}\text { Methyl- } \\
\text { testosterone }\end{array}$ & $\begin{array}{l}0.05 \\
0.5\end{array}$ & $\begin{array}{l}7 \\
8\end{array}$ & $\begin{array}{l}291 \pm 69 \\
246 \pm 48\end{array}$ & $\begin{array}{l}2.1 \pm 1.4^{*} \\
0.4 \pm 0.2^{* * *}\end{array}$ & $\begin{array}{l}1.1 \pm 0.1 \\
1.4 \pm 0.2\end{array}$ & $\begin{array}{l}2.1 \pm 0.3 \\
2.5 \pm 1.2\end{array}$ & $\begin{array}{r}0 \\
100\end{array}$ & $\begin{array}{r}50 \\
0\end{array}$ \\
\hline Estradiol-17 $\beta$ & 0.5 & 4 & $164 \pm 19$ & $0.4 \pm 0.3 * * *$ & $3.9 \pm 0.5 * *$ & $1.7 \pm 0.5$ & 100 & 0 \\
\hline Hexestrol & $\begin{array}{l}0.05 \\
0.5\end{array}$ & $\begin{array}{l}8 \\
7\end{array}$ & $\begin{array}{l}275 \pm 98 \\
310 \pm 65\end{array}$ & $\begin{array}{l}6.2 \pm 0.3 \\
6.3 \pm 1.9\end{array}$ & $\begin{array}{l}1.3 \pm 0.3 \\
1.2 \pm 0.1\end{array}$ & $\begin{array}{l}1.6 \pm 0.4 \\
1.5 \pm 0.3\end{array}$ & $\begin{array}{l}0 \\
0\end{array}$ & $\begin{array}{l}100 \\
100\end{array}$ \\
\hline Progesterone & $\begin{array}{l}0.5 \\
5\end{array}$ & $\begin{array}{l}7 \\
7\end{array}$ & $\begin{array}{l}239 \pm 81 \\
293 \pm 57\end{array}$ & $\begin{array}{l}5.9 \pm 0.7 \\
1.8 \pm 0.4 *\end{array}$ & $\begin{array}{l}1.4 \pm 0.2 \\
1.3 \pm 0.3\end{array}$ & $\begin{array}{l}1.3 \pm 0.2 \\
1.8 \pm 0.4\end{array}$ & $\begin{array}{l}0 \\
0\end{array}$ & $\begin{array}{l}100 \\
100\end{array}$ \\
\hline FGA & 0.5 & 8 & $239 \pm 63$ & $4.6 \pm 1.8$ & $1.1 \pm 0.1$ & $1.9 \pm 0.7$ & 12 & 88 \\
\hline
\end{tabular}

Note: $*, P<0.5 ; * *, P<0.01 ; * * *, P<0.005$ compared with the control.

a Number of fish at the end of the experiment (18 November 1975). The initial number was 15 in each group.

${ }^{b}$ Pituitary weight in milligrams per kilogram total body weight (fresh weight).

cPercentage males with regressed testes (GSI $<0.5$ ).

${ }^{d}$ Males showing signs of sperm release after manual pressure on the abdomen.

Accidental mortality occurred: 6 males were still alive on 27 September; individual values are given.

the food. A control group received normal pellets without steroids. The diet was fed once a day between 11:00 a.m. and noon, 6 days a week at the rate of $1 \%$ body weight. The pellets were stored frozen $\left(-20^{\circ} \mathrm{C}\right)$. The fish were periodically anesthetized, weighed, and bled by heart puncture to obtain samples for plasma trout gonadotropin (t-GTH) measurement by radioimmunoassay, according to the technique of Breton et al. (1971) for carp gonadotropin (c-GTH). At the end of the experiment (November 18), when all the control males showed signs of sperm release, all the fish were killed; the body, gonads, liver and pituitaries were weighed, and the gonadosomatic index (GSI), hepatosomatic index (HSI), and pituitarysomatic index (PSI) were calculated. The testes were fixed in Bouin-Holland and the $7-\mu \mathrm{m}$ sections were stained with hematoxylin for histological examination.

\section{Experiment $B$-treatment during spermiation}

Two-summer-old males (150-200 g), showing early signs of sperm release, were taken from the Forgeot fish farm in mid-November and held in our laboratory under the same conditions as in experiment $\mathrm{A}$. They were divided into groups fed ( $1 \%$ body weight) pellets containing the sex steroids listed in Table 2 from November 26 to February 16. Their blood was sampled periodically for plasma t-GTH measurement, as in experiment A; after the sperm was collected in 5-mL tubes, it was measured and the spermatocrit determined $(17000 \times g$ for $15 \mathrm{~min}$ ), according to Bouck and Jacobson (1976). On January 23 , sperm fertilizing ability was determined by inseminating the pooled eggs of several females, according to the technique of Billard (1977) using diluent (1/1000 dilution). Percentage of normal and abnormal embryonated eggs was established just before hatching (around 300 degree-days). Water temperature fluctuated between 6 and $11^{\circ} \mathrm{C}$ during the experiment. The fish caught a severe fungus infection and were treated with malachite green $(5 \mathrm{mg} / \mathrm{L})$ for $15 \mathrm{~min}$ twice a week.

The data were statistically compared by analysis of variance after $\log$ transformation.

\section{Results}

\section{Experiment $A$}

The data in Table 1 show that inhibition of gonadal development was total in the fish treated with methyltestosterone (MT) and estradiol-17 $\beta\left(\mathrm{E}_{2}\right)$ at a dose of $0.5 \mathrm{mg} / \mathrm{kg}$ of food. At the same dose, testosterone (T) induced complete testicular regression in only 5 out of 9 males. At $0.05 \mathrm{mg} \mathrm{MT} / \mathrm{kg}$ of food, partial inhibition of testicular development and inhibition of spermiation were obtained in a few males. The other treatments had no effect on gonadal development, except that a high dose of progesterone $(\mathrm{Pg})$ stimulated and advanced spermiation, leading to a significant decrease in the GSI. The HSI of the $\mathrm{E}_{2}$-treated group was significantly higher $(P<0.005)$ than in the controls. The PSI was also higher $(P<0.01)$ for the group treated with the highest dose of $\mathrm{T}$. The overall mortality rate was high in all groups; in the $E_{2}$-treated group, the mortality rate was especially high, and the surviving fish were thin, having lost weight.

Histological examination revealed varying degrees of spermatogenetic inhibition. With $\mathrm{T}$, necrotic cells appeared in the lumen of the seminiferous lobule (Fig. 1) where they remained packed together (Fig. 2). They were also found in highly regressed testes after MT treatment that eliminated most of the germ cells and suppressed the seminiferous lobule structure (Fig. 3). The $E_{2}$ treatment also induced marked testicular regression (Fig. 4). In such highly regressed testes (6 out of 30 fish in the T, MT, and $\mathrm{E}_{2}$ groups), no true germ cells could be identified. In less regressed testes, careful examination revealed some germ cells (primary germ cells or type-A spermatogonia) lying on the layer of 
TABLE 2. Some effects of steroid treatment during spermiation in rainbow trout (mean values \pm SD)

\begin{tabular}{|c|c|c|c|c|c|c|c|c|c|c|}
\hline Control & 0 & 10 & 8 & $221 \pm 19$ & $2.04 \pm 0.6$ & $1.19 \pm 0.7$ & $2.1 \pm 0.7$ & 16.7 & 309 & $96 \pm 1$ \\
\hline Testosterone & 0.5 & 12 & 6 & $158 \pm 17$ & $1.54 \pm 0.3$ & $1.55 \pm 0.4$ & $2.3 \pm 0.4$ & 12.1 & 195 & $67 \pm 18 * * *$ \\
\hline Estradiol-17 $\beta$ & $\begin{array}{ll}\beta & 0.5 \\
\end{array}$ & 12 & 4 & $209 \pm 20$ & $2.94 \pm 1.4$ & $2.41 \pm 0.8$ & $2.3 \pm 0.9$ & 18.4 & 171 & $80 \pm 34$ \\
\hline
\end{tabular}

NOTE: ***, $P<0.005 ; * *, P<0.01$.

aTotal volume of sperm collected during the experiment.

b Total number of spermatozoa collected during the experiment.

cPercentage of embryonated eggs before hatching.
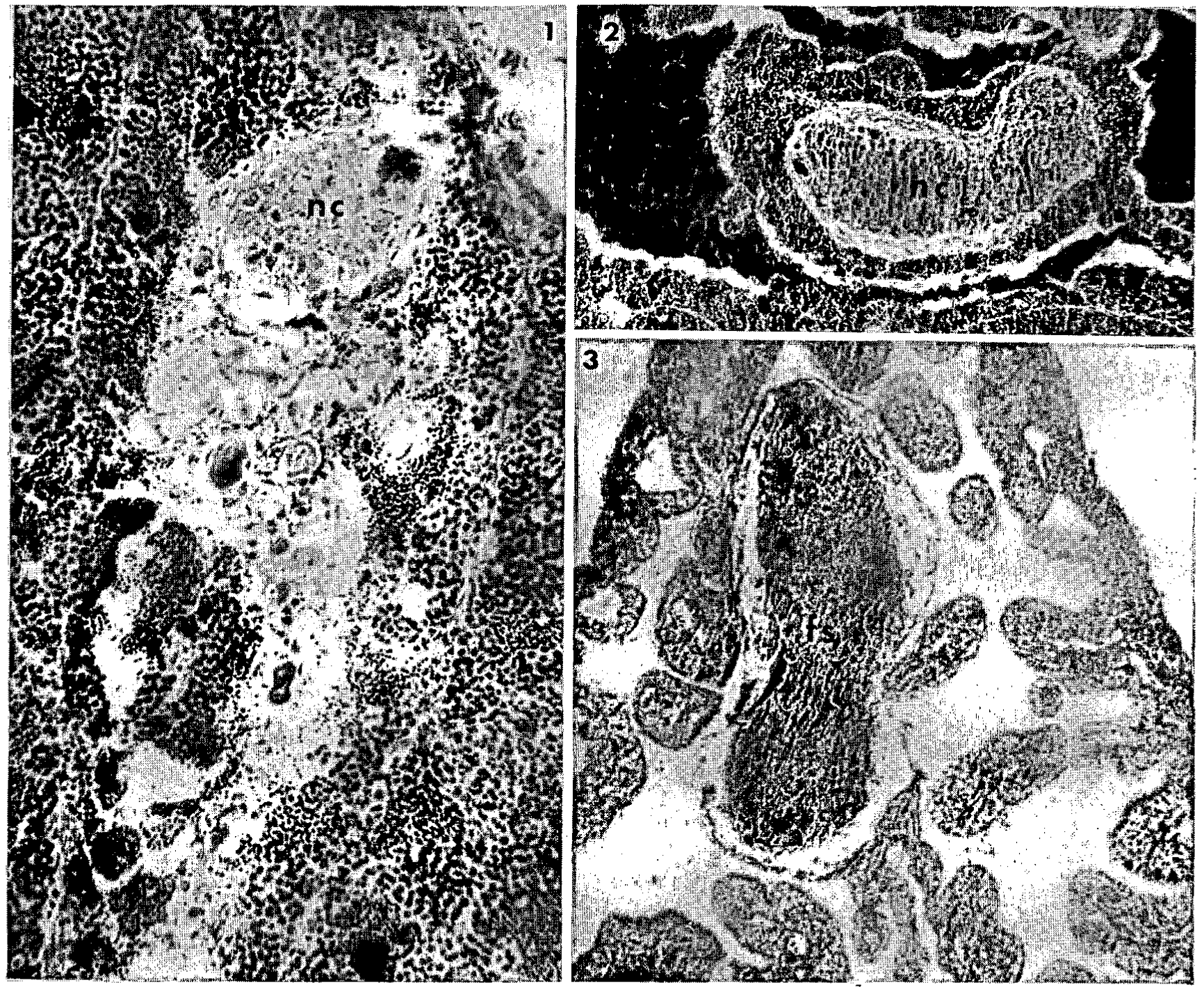

FIG. 1. Testosterone treatment $(0.05 \mathrm{mg})$ : necrotic cells $(n c)$ in the lumen of a seminiferous lobule. $\times 180$. Fig. 2 . Testosterone treatment $(0.05 \mathrm{mg})$ : bundle of necrotic cells $(n c)$ in a compact structure in the lumen of seminiferous lobule. $\times 70$. FIG. 3 . Methyltestosterone treatment $(0.5 \mathrm{mg})$ : regressed testis. The fibrous structure $(f s)$ is probably a remnant of the necrotic cells seen in Figs. 1 and 2. $\times 70$.

somatic cyst cells (Sertoli cells) surrounding the seminiferous lobule (Fig. 5). These germ cells sometimes remained functional since little spermatogenetic activity could be seen in this less regressed testis (Fig. 6).
The changes in GTH during the experimental period are shown in Fig. 7. Plasma t-GTH was never zero in the groups that showed complete inhibition of testicular development. Only the rise of GTH was prevented in the 

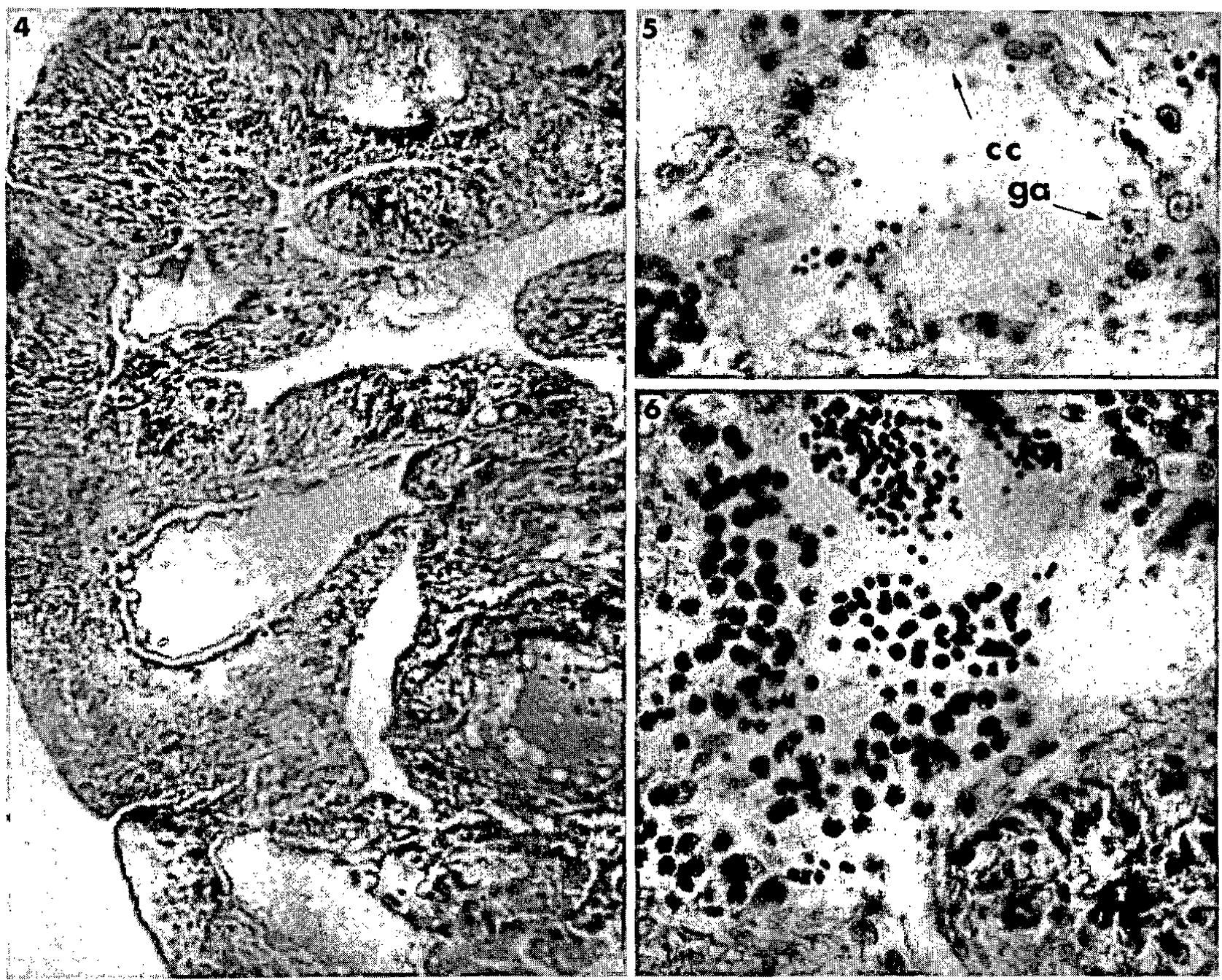

Fig. 4. Estradiol- $17 \beta$ treatment $(0.5 \mathrm{mg})$ : regressed testis. $\times 70$. Fig. 5 . Methyltestosterone treatment $(0.5 \mathrm{mg})$ : orthogonal section of a lobule with a germ cell $(\mathrm{ga})$ included in the layer of cyst cells $(\mathrm{cc}) . \times 450$. FIG. 6 . Testosterone treatment $(0.5 \mathrm{mg})$ : some spermatogenetic activity seen in a regressed testis. $\times 450$.

groups treated with $0.5 \mathrm{mg}$ of $\mathrm{T}, \mathrm{MT}$, or $\mathrm{E}_{2}$ and showing inhibition of spermatogenesis. In the other groups, this rise in GTH was sometimes advanced (case of progestogens) and amplified.

\section{Experiment $B$}

When the experimental food was given during the period of spermiation after spermatogenesis was completed, the GSI (Table 2) and histological examination showed no gonadal regression. Only some bundles of necrotic cells, similar to those identified in experiment $A$, were found in the $E_{2}$ - and T-treated groups (Figs. 1, 2). The appearance of all the other fish tested was normal; the lobules were filled with spermatozoa. No other germ cells were present, except type-A spermatogonia lying at the lobular border. In the T-group, spermatozoal density in the lobular lumen was lower (Fig. 8) than in the control fish (Fig. 9), suggesting that the spermatozoa had been released; however, this effect was limited since no significant change in testicular weight was observed. Changes in the volume of sperm collected during the experiment are shown in Fig. 10, and the total volume is given in Table 2. Steroid treatment tended to delay the rise of sperm production observed in the controls. There was wide individual variation in sperm volume (coefficient of variation: around $50 \%$ ) and the differences between groups were not significant.

During the same period, the spermatocrit decreased in a similar way in each group. Using the spermatocrit, we calculated the total number of spermatozoa collected (Table 2); this number was smaller in the treated groups. Sperm fertilizing ability was significantly decreased in the T-treated group and no major abnormality was observed in the embryos. Changes in t-GTH (Fig. 11) showed a very high increase of secretion in the $E_{2^{-}}$ treated group; this rise was not followed by a rise in sperm production. In the other steroid-treated groups, GTH tended to decline and was signficantly lower than in the controls on day 42 .

\section{Discussion}

The effects of sex steroids given in the diet varied according to dose, type of steroid, and stage of testicular 


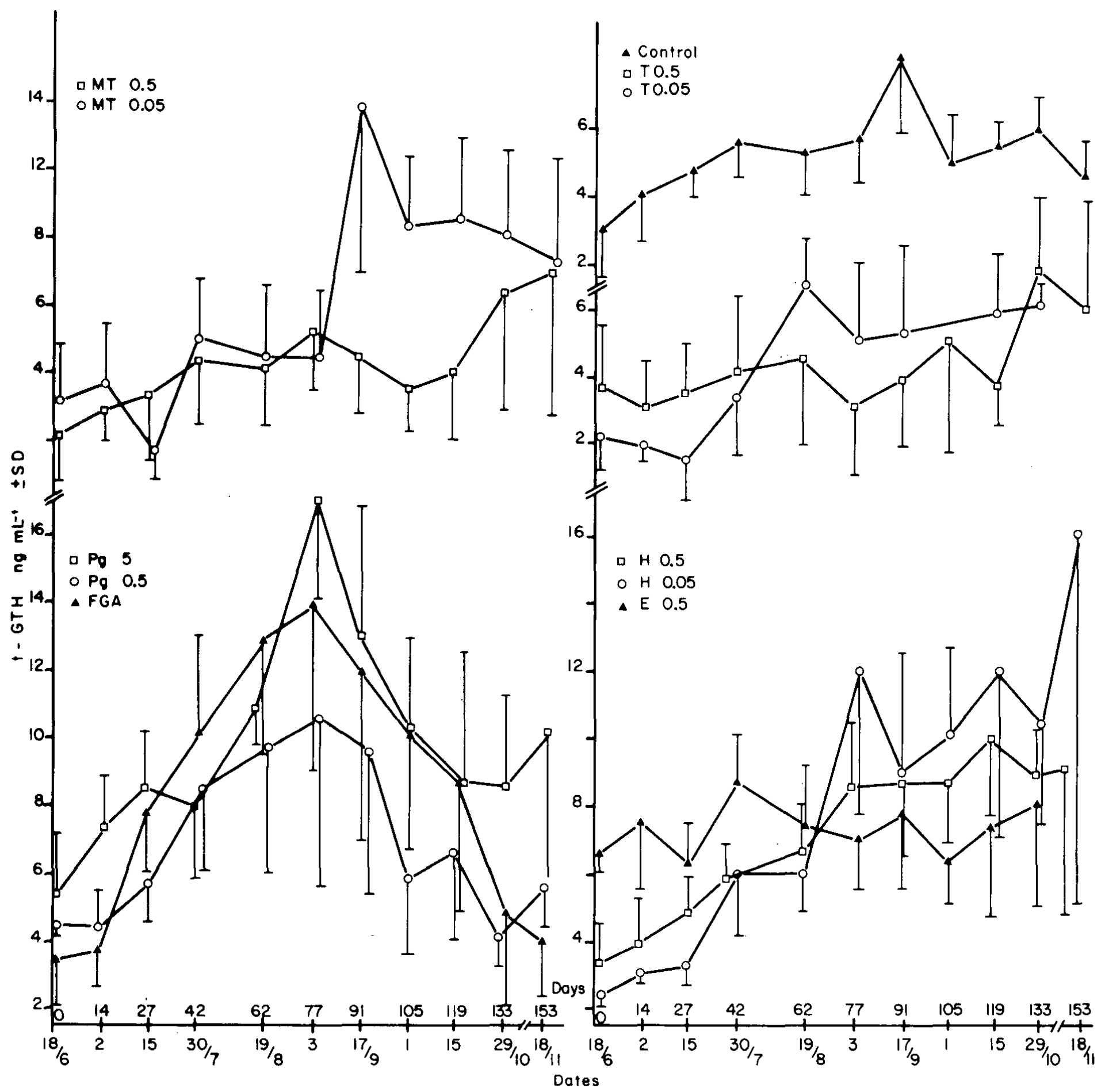

FIG. 7. Treatment with various steroids added to the food: plasma GTH changes (experiment A).

development at the time of treatment. When given during active spermatogenesis, $\mathrm{T}, \mathrm{MT}$, or $\mathrm{E}_{2}$ totally or partially inhibited spermatogenesis. During the period of spermiation or after spermatogenesis had been completed, the effect was more limited.

The structural changes in the testis after MT or $E_{2}$ treatment were dramatic: no lobular structure was found; the wall of the testis was thick, as already shown after MT treatment by Fagerlund and McBride (1975); and inside were folds of tissue lined with an epithelium (Fig. 3) that might be secretory (Fig. 4). This epithelium was similar to that in the vas deferens. In such highly regressed testes, it was nearly impossible to identify true germ cells in the epithelium that were different from the normal somatic supporting cells (Sertoli cells) present in the typical seminiferous tubule (Fig. 5). In these conditions, structural alteration of the testis and its organization in lobules surrounded by Sertoli cells might lead to the elimination of germ cells and induce sterility. Spermatogenetic loss was seen in juvenile coho salmon after MT treatment by McBride and Fagerlund (1973) and Fagerlund and McBride (1977), but not in oneyear-old rainbow trout treated with 4-chlorotestosterone acetate (Hirose and Hibiya 1968). 

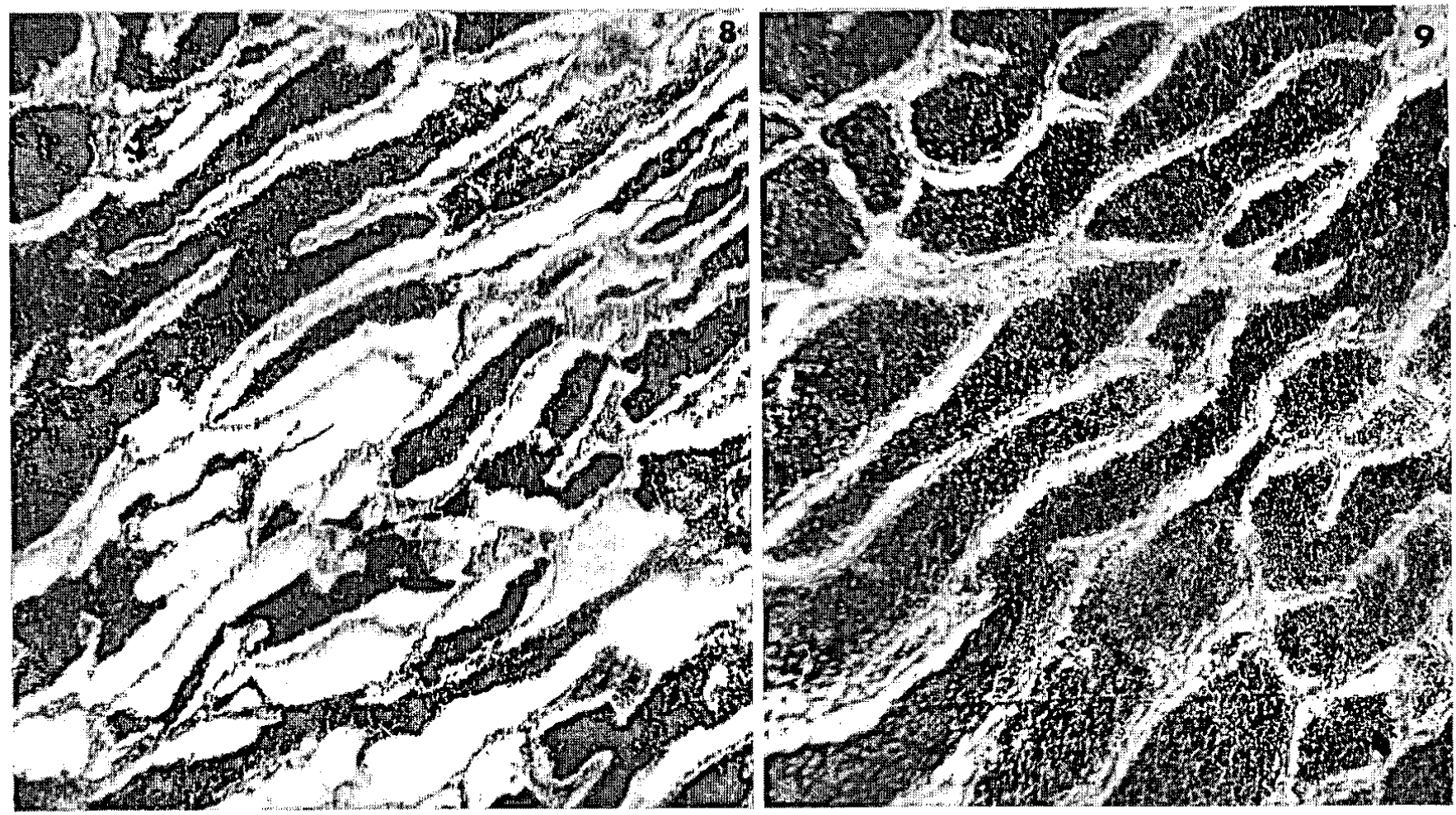

FIG. 8. Testosterone treatment $(0.5 \mathrm{mg})$ during spermiation: partially emptied lobule in the testis. $\times 70$. FIG. 9 . Control male at the end of the experiment: lobule in testis filled with spermatozoa. $\times 70$.
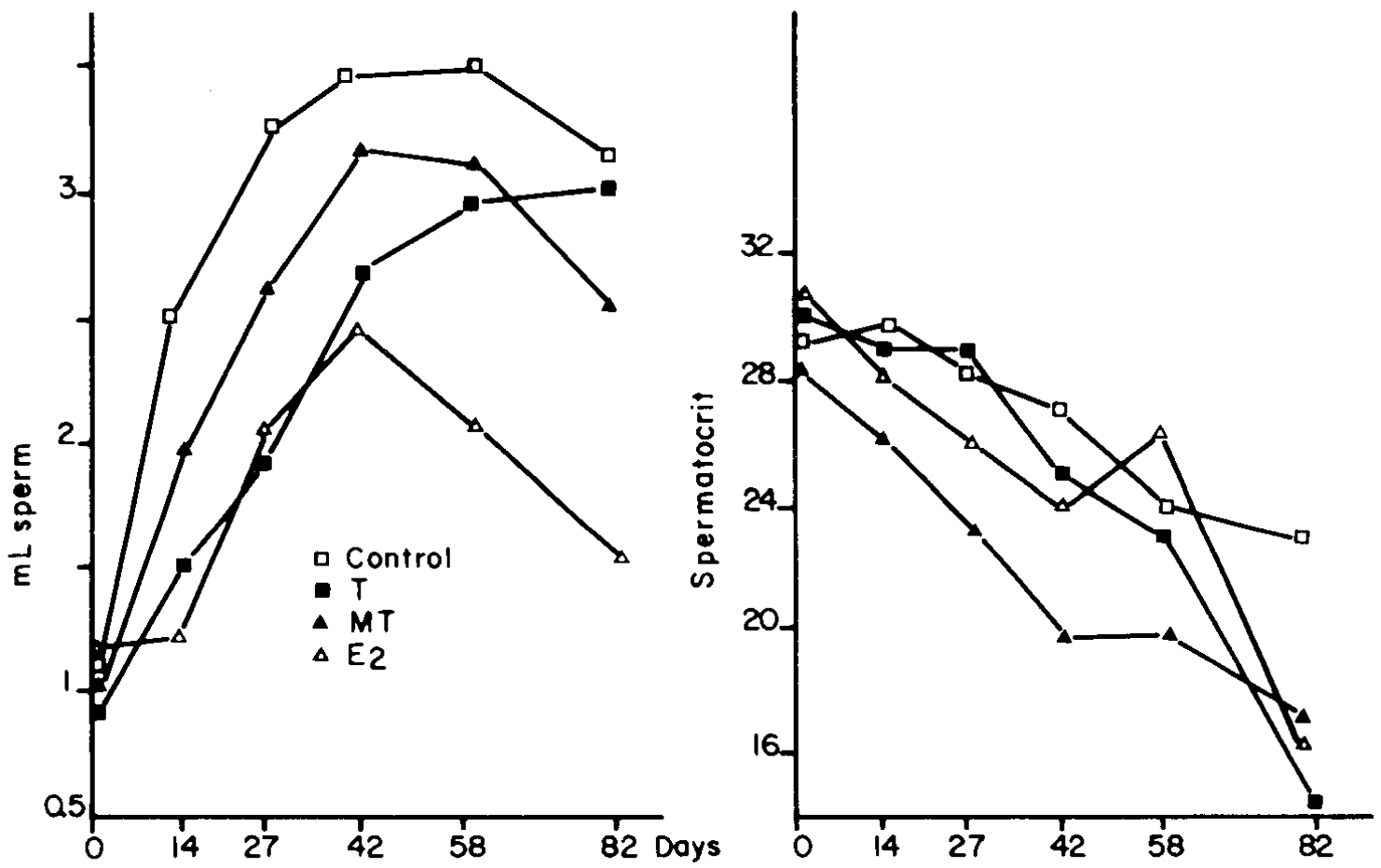

FIG. 10. Changes in the total volume of sperm (in millilitres) collected at each sampling during the experimental period.

In our experiment, these highly regressed testes may be sterile, but a recovery period is necessary to determine if spermatogenesis can be reinitiated. It is interesting to note that the structure of the highly regressed gonad is similar to that of the ovary, suggesting interference of sex steroids with the factors responsible for gonadogenesis. Although complete male feminization is obtained after steroid treatment of juveniles (Johnston et al. 1978; Johnston et al. 1979; Goetz et al. 1979), it appears that feminization in adults is only somatic and no sex reversal is found. Again, some time should be allowed for checking to see if germ cells are still present and whether they function in the male or female direction. 


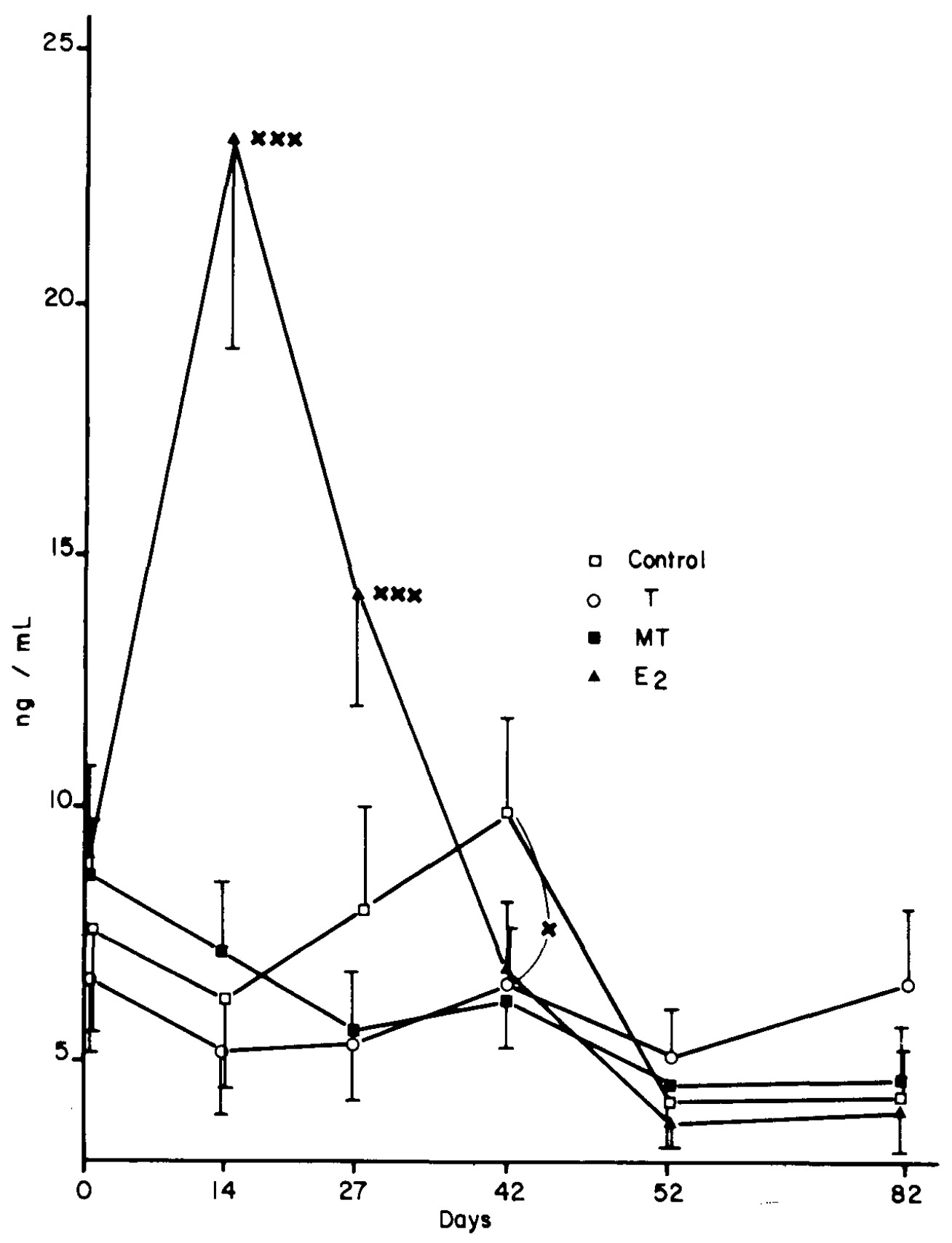

FIG. 11. Changes in plasma t-GTH in a male receiving various steroids added to the diet during the period of spermiation (experiment B). $\times, P<0.05 ; \times \times \times, P<0.005$; compared with control group.

When steroid treatment is given to females, the results vary with age. The structural changes in juvenile females are not as important as those in males (Jalabert et al. 1975; Fagerlund and McBride 1975; Yu et al. 1979). In adult rainbow trout, inhibition of vitellogenesis was reported after treatment with 4-chlorotestosterone (Hirose and Hibiya 1968), MT (Yamazaki 1972), and T, MT, and $E_{2}$ (Billard et al. 1981), but the basic structure of the ovaries was unchanged. Oogonia, meiotic oocytes, and somatic cells maintained a normal appearance in the treated ovaries. It seems therefore that germ cells are more resistant to steroid treatment in ovaries than in testes.

This fits with an hypothesis of a primary sex steroid effect on the structure of the male gonad and on the somatic supporting cells, leading to elimination of the primary germ cells and spermatogonia. The fact that the testis did not respond to circulating GTH (which remained nearly as high as in the controls) also suggests that the somatic compartment (supporting germ cells or steroidogenic cells) was altered by the steroid treatment.

The degree of testicular regression was quite variable among the males, and the intensity of structural alteration might depend on the stage of spermatogenesis reached when the steoid treatment started. It is known that the time when spermatogenesis is initiated varies (between May and July in our population); in a previous experiment, it was shown that the inhibitory effect of antiandrogens on testicular development was more important when the treatment started before spermatogenesis was established ( $R$. Billard, unpublished data).

This is also illustrated by the fact that steroid 
treatment, although shorter in experiment B than in experiment $\mathrm{A}$ and given after completion of spermatogenesis, neither changed the structure of the testis nor caused the elimination of type-A spermatogonia. It seems therefore that the immature gonad or the resting gonad is more sensitive to steroid treatment than the fully mature testis. At that stage, the structure of the lobule and the existence of a blood testis barrier (Marcaillou and Szöllösi 1980) may protect the somatic and germinal elements and limit the entrance of steroids into the lobule.

The suppressive effects of the androgens on the testis might be dose dependent; McBride and Fagerlund (1973) observed a decrease in the number of spermatogonia in MT-treated coho salmon and mentioned that changes were more pronounced in males held on maximum concentration of hormone. On the other hand lower dose of MT may be stimulative according to Fagerlund and McBride (1977). In the present experiment a possible stimulation of spermatogenesis may have occurred in the T-treated group $(50 \mu \mathrm{g})$, but no definitive conclusion can be drawn because of the small number of males surviving at the end of the experiment.

Progestogens (progesterone and Fluorogestone acetate) had no deleterious effect on spermatogenesis detected on histological sections. The significant drop in testicular weight observed in the progesterone-treated group was probably due to stimulation of the spermiation process, as seen after progesterone injection in this species (G. de Montalembert and R. Billard, unpublished data) as well as in pike (de Montalembert et al. 1978) and goldfish (Billard 1976). The other steroids did not stimulate the spermiation process, even when given during the period of full maturity (experiment B), as shown by the number of spermatozoa collected (Table 2). T or MT had no effect, although each has been shown to stimulate spermiation in trout $(\mathrm{G}$. de Montalembert and R. Billard, unpublished data) and goldfish (Yamazaki and Donaldson 1969; Billard 1976). The rise in plasma immunoreactive t-GTH recorded after $\mathrm{E}_{2}$ treatment was not followed by stimulation of spermiation, perhaps indicating changes in spermatogenesis, even though these changes were not seen by histological examination. After completion of spermatogenesis, the steroid treatment had some effects at the level of the hypothalamo-pituitary axis since $E_{2}$ increased the level of plasma GTH. In addition, pituitary weight was significantly increased in the MT group, suggesting a positive $E_{2}$ feedback mechanism, as observed in juvenile fish by Crim and Evans (1979). Fertility of the spermatozoa estimated by the percentage of embryonated eggs before hatching was significantly decreased in the T group (experiment B). As no noticeable embryo mortality or abnormality was observed, this drop of fertility was probably due to a decrease of fertilizing capacity of the spermatozoa at the time of artificial insemination. This result is difficult to explain; T may have initiated inadequate seminal plasma quality or accelerated the process of spermiation more rapidly than MT or $E_{2}$, leading to a prolonged stay of the spermatozoa in the vas deferens where they may have undergone process of ageing.

\section{Acknowledgement}

This work was supported by Institut Nationel de la Recherche Agronomique and Centre Nationel pour l'Exploitation des Oceans grants. The English version of the manuscript is due to Mrs. Daifuku.

BILLARD, R. 1976. Induction of sperm release in the goldfish by some steroids. IRCS, 4: 42 .

1977. A new technique of artificial insemination for salmonids using a sperm diluent. Fisheries, 1: 24-25.

BILlARD, R., M. RichaRd, and P. Rombauts. 1981. Inhibition of spermatogenesis and vitellogenesis in rainbow trout by estradiol and methyltestosterone included in the diet. Progr. Fish Cult. In press.

BoucK, G. R., and J. JACOBSON. 1976. Estimation of salmonid sperm concentration by microhematocrit technique. Trans. Am. Fish. Soc. 105: 534-535.

Breton, B., G. KanN, E. Burzawa-Gérard, and R. BILlARD. 1971. Dosage radioimmunologique d'une hormone gonadotrope de carpe Cyprinus carpio L. C.R. Acad. Sci. Paris, Ser. D, 272: 1515-1517.

Crim, L. W. , and D. M. Evans. 1979. Stimulation of pituitary gonadotropin by testosterone in juvenile rainbow trout (Salmo gairdneri). Gen. Comp. Endocrinol. 37: 192-196. De Montalembert, G., C. BRY, and R. Billard. 1978. Control of reproduction in northern pike (Esox lucius). Am. Fish. Soc. Spec. Publ. 11: 217-225.

FAGERLund, U. H. M., and J. R. MCBRIDE. 1975. Growth increments and some flesh and gonad characteristics of juvenile coho salmon receiving diets supplemented with $17 \alpha$-methyltestosterone. J. Fish. Biol. 7: 305-314.

- 1977. Effect of $17 \alpha$-methyltestosterone on growth, gonad development, external features and proximate composition of muscle of steelhead trout, coho and pink salmon. Fish. Mar. Serv. Tech. Rep. No. 716.

FAgerlund, U. H. M., J. R. McBride, and E. T. Stone. 1979. A test of $17 \alpha$-methyltestosterone as a growth promoter in a coho salmon hatchery. Trans. Am. Fish. Soc. 108: $467-472$.

Goetz, F. W., E. M. Donaldson, G. A. Hunter, and H. M. DYE. 1979. Effects of estradiol-17 $\beta$ and $17 \alpha$-methyltestosterone on gonadal differentiation in the coho salmon, Oncorhynchus kisutch. Aquaculture, 17: 267-278.

Higgs, D. A., U. H. M. FAgerlund, J. R. McBRide, H. M. DYE, and E. M. DonALDSON. 1977. Influence of combinations of bovine growth hormone, $17 \alpha$-methyltestosterone and $\mathrm{L}$-thyroxine on growth of yearling coho salmon (Oncorhynchus kisutch). Can. J. Zool. 55: 1048-1056.

Hirose, K., and T. HibiYa. 1968. Physiological studies on growth-promoting effect of protein-anabolic steroids on fish. II. Effects of 4-chlorotestosterone acetate on rainbow trout. Bull. Jpn. Soc. Sci. Fish. 34: 473-481. 
Jalabert, B., R. Billard, and B. Chevassus. 1975. Preliminary experiments on sex control in trout: production of sterile fishes and simultaneous self-fertilizable hermaphrodites. Ann. Biol. Anim. Biochim. Biophys. 15: 19-28.

Johnstone, R., T. H. Simpson, and H. F. Youngson. 1978. Sex reversal in salmonid culture. Aquaculture, 13: 115-134.

Johnstone, R., T. H. Simpson, and A. F. Walker. 1979. Sex reversal in salmonid culture. Part III. The production and performance of all-female populations of brook trout. Aquaculture, 18: 241-252.

MarCaillou, C., and A. Szöllösi. 1980. The "bloodtestis" barrier in a nematode and a fish: a generalizable concept. J. Ultrastruct. Res. 70: 128-136.

McBride, J. R., and U. H. M. FAGERLUND. 1973. The use of $17 \alpha$-methyltestosterone for promoting weight increases in juvenile pacific salmon. J. Fish. Res. Board Can. 30: 1099-1104.
1976. Sex steroids as growth promoters in the cultivation of juvenile coho salmon (Oncorhynchus kisutch). Proceeding of the 7th American Meeting of the World Mariculture Society, 1976. pp. 145-161.

YAMAZAKI, F., 1972. Effects of methyltestosterone on the skin and the gonad of salmonids. Gen. Comp. Endocrinol. 3: 741-750.

1976. Application of hormones in fish culture. J. Fish. Res. Board Can. 33: 948-958.

YAMAZAKI, F., and E. M. DonALDSON. 1969. Involvement of gonadotropin and steroid hormones in the spermiation of the goldfish (Carassius auratus). Gen. Comp. Endocrinol. 12: 491-497.

Yu, T. C., R. O. Sinnhuber, and J. D. Hendricks. 1979. Effect of steroid hormones on the growth of juvenile coho salmon (Oncorhynchus kisutch). Aquaculture, 16: 351359. 